У, $\triangle \mathrm{K} 351: 349.2$

ББК 67.401.12+67.405.1

DOI 10.22394/1682-2358-2020-3-67-72

A.A. Ivanov, Candidate of Sciences (Law), Senior Lecturer of the Labor Law Department, Saratov State Academy of Law

Yu.A. Kondrashov, Candidate of Sciences (Law), Docent of the Theory of State and Law Department, Saratov State Academy of Law

\section{IMMORAL \\ MISCONDUCT \\ OF A TEACHER: \\ CONCEPT \\ AND PRACTICE OF APPLICATION}

Labor relations between teachers and management of general educational institutions are studied in the plane of termination of an employment contract with an employee at the employer's initiative for a teacher's immoral misconduct. Particular attention is paid to identifying possible criteria for immorality of a teacher's misconduct. Based on judicial practice and theoretical approaches, the author offers his definition of immoral misconduct and a list of actions that law enforcement should consider.

Key words and word-combinations: criteria for immorality of misconduct, committing immoral misconduct in everyday life, employer discretion, teacher.
A.А. ИВаноВ, кандидат юридических наук, стариий преподаватель кафедрь трудового права Саратовской государственной юридической академии (email: artiom-depeche@yandex.ru)

Ю.А. Кондрашов, кандидат юридиеских наук, доиент кафедри теории государства и права Саратовской государственной юридической академии (email: yakondor@mail.ru)

\section{АМОРААЬНЫЙ ПРОСТУПОК ПЕААГОГИЧЕСКОГО РАБОТНИКА: \\ ПОНЯТИЕ И ПРАКТИКА ПРИМЕНЕНИЯ}

Аннотащия. Исследуются трудовые отношения между педагогами и руководством общеобразовательных учреждений в плоскости расторжения с работником трудового договора по инициативе работодателя за совершение педагогом аморального проступка. Уделяется особое внимание выявлению возможных критериев аморальности проступка педагога. Основываясь на судебной практике и теоретических подходах, авторы предлагают собственное определение аморального проступка и перечень действий, которые следует учитывать правоприменителям.

Ключевые слова и словосочетания: критерии аморальности проступка, совершение аморального проступка в быту, усмотрение работодателя, педагог.

$\Pi$ роблемные правовые вопросы применительной практики в сфере народного образования остаются по-прежнему актуальными. Наиболее змободневными явмяются 
проблемы, связанные с расторжением с работником, осуществцяющим воспитательные функции, по инициативе работодателя трудового договора за совершение аморацьного проступка. Аанное понятие, закрепленное в Трудовом кодексе Российской Федераџии (ТК РФ) [1], вызывает множество вопросов как с позиџии законодательства, так и судебной практики, и является предметом дискуссий ученых-правоведов. Недавние сообщения средств массовой информаџии дают повод утверждать, что упоминающееся в ТК РФ понятие аморального проступка требует исследования и с теоретической, и практической точки зрения [2]. В Аанной публикации попытаемся представить авторское аргументированное мегальное определение аморацьного проступка; сформулировать конкретные законодательные критерии аморацьности проступка пеАагогического работника; предложить перечень Аеяний, которые следует считать аморальным проступком. Предложенные рекомендации, на наш взгляА, позволят искмючить в Аальнейшем субъективное толкование судами и работодателями того, что следует считать аморацьным проступком.

Аморальный проступок, в отличие от правонарушения, не находит своего закрепления в законодательстве, поэтому часто возникают вопросы, что следует считать аморацьным? Критериев, квалифицирующих признаки аморальности тех или иных действий работника, в законодательстве не прописано, в отличие от аморальных деяний, прямо закрепленных законом. В связи с этим вопросы степени аморацьности и расторжения трудового договора с работником остаются на усмотрение работодателя. По мнению ученых, расторжение трудового Аоговора по иниџиативе работодателя по указанному основанию может быть произведено только при наличии зафиксированного конкретного аморального проступка [3, с. 33]. Подобный подход существует и в трудовом законодательстве стран СНГ [4] .

Не будет ошибкой считать, что норма об аморальном проступке, предусмотренная ст. 81 ТК РФ, тождественна норме, закрепиенной в п. 2 ст. 336 ТК РФ о психическом и физическом насилии педагогом наА мичностью учащегося. Это еще раз подтверждает, что законодатель не дает подробного мегального объяснения того, что следует понимать под аморальным проступком. Ни в законоАательстве, ни в судебной и административной практике не сложилось также единообразного подхода и к критериям аморальности действий работника, осуществляющего воспитательные функции.

Исходя Из ПодХодов, слоЖившихся в митературе За послеАНИе гоАЫ По

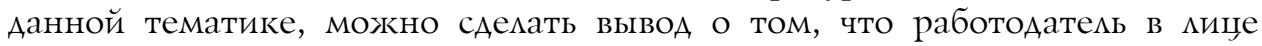
аАминистрации образовательной организации ими судья при вынесении решения о том, насколько были аморацьны действия работника, опираются мишь на собственные убежжения. По нашему мнению, такой подход неАопустим, так как сложившаяся негативная практика может впоследствии сломать карьеру работнику. При решении подобных вопросов следует обращать внимание на такие факторы, как психическое состояние работника в момент совершения проступка и отношение к трудовым обязанностям

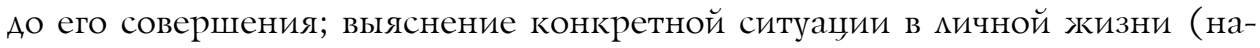


пример, развод, смерть или тяжелая болезнь родственника и т.п.); относительность понятия мораци и субъективные представления о ней разными мюАьми. В ст. 81 ТК РФ аморацьный проступок в плоскости ее применения носит коррупционный характер. Таким образом, у работодателя имеется полный карт-бцанш увольнять неугодных сотрудников исходя из собственных убеждений об общественной морали, которая к тому же является Аовольно переменчивой.

Усугубляет положение педагогического работника и тот факт, что норма об аморальном проступке распространяется на него вне зависимости от нахожАения на территории образовательной организации. Подобное применение п. 8 ст. 81 ТК РФ Аелает преподавателя заложником своей профессии. Он становится юридически слабой стороной по сравнению с Аругими участниками образовательных отношений, например родителями учащихся. Модель поведения, нравственное развитие и воспитание детям прививаются дома. ОАнако ни в одном нормативно-правовом акте нет нормы о привлечении родителей обучающихся к ответственности по аналогичной норме. ПреАставляется целесообразным предусмотреть в ст. 44 Федерацьного закона от 29 Аекабря 2012 г. № 273-ФЗ «Об образовании в Российской ФеАерации» [5] новый пункт 7, который содержал бы норму о привлечении родителей (законных представителей) учащихся за аморальное поведение.

В российском законодательстве нет законодательного акта, содержащего мегальную дефиницию аморацьного проступка. ОАнако она имеется в нормах межлународного права. Так, заслуживает внимания Рекомендация о статусе преподавательских кадров учреждений высшего образования [6]. Под аморальным проступком в нем понимается следующее: подАелка или фальсификация результатов научных исследований; чрезмерные финансовые нарушения; сексуальные домогательства или другое неправомерное поведение в отношении учащихся, комлег или других представителей академического сообщества, высказывания серьезных угроз в их адрес; извлечение противоправной выгоды из учебного процесса путем фальсификации свидетельств, Аипломов и степеней за денежное вознаграждение. В Рекомендации также предусмотрена норма о том, что не имеет значения место совершения аморального проступка - на рабочем месте или в быту.

Очевидно, в ТК РФ необходима специальная норма, предусматривающая не только мегальное определение аморального проступка, но и перечень действий, подпадающих под него.

Суды и работодатели самостоятельно определяют аморальность совершенного проступка, что вносит путаницу в практику правоприменения. Опираясь на анализ судебной практики, можно назвать следующие деяния, подпадающие под категорию аморацьного проступка: применение физической силы в отношении несовершеннолетнего или комлеги, родственника; скандалы с колмегами и родственниками; употребление спиртных напитков, наркотических веществ в общественном месте, появление в состоянии опьянения в общественном месте, а также вовлечение в это несовершеннолетних; использование ненормативной цексики в присутствии несовершеннолетних; негативная 
оџенка Аругих преподавателей и администрации учебного заведения; понужАение детей к Аействиям сексуального характера (даже если привлечения к уголовной ответственности не было); понуждение воспитанника к обману; написание диссертаций на заказ; подработка по совместительству в ночном кмубе [7; 8].

Таким образом, можно сделать вывод о том, что в сложившихся реалиях, исходя из судебной практики и отсутствия еАиных законодательных критериев аморацьности анализируемого проступка, следует предусмотреть в ТК РФ его конкретные квалифиџирующие признаки с целью предотвращения субъективного толкования работодателем или судом аморальности деяния.

В ТК РФ необходимо также закрепить цегацьное определение аморального проступка работника, выполняющего воспитательные функщии. По нашему мнению, аморацьный проступок - это деяние, несовместимое с дальнейшей работой, если этот проступок оказац негативное воздействие на целевую аудиторию или дает основания предполагать, что сотрудник может в Аальнейшем совершить аналогичное или подобное деяние. Считаем верным рекомендовать закрепить перечень Аеяний, квацифицирующихся как аморальный проступок: вовлечение несовершеннолетних в распитие алкогольных напитков; мелкое хулиганство; совершение в присутствии обучающихся (воспитанников) непристойных телодвижений; принуждение обучающихся совершать Аействия, унижающие их достоинство; причинение физических страданий; издевательство и жестокое обращение с животными в присутствии обучающихся (воспитанников). Аанный перечень соотносится с преАможением Санкт-Петербургского городского суда (определение от 20 дек. 2011 г. № 33-18965/2011) [9] .

Аморальный проступок явмяется специальным основанием Аля расторжения трудового Аоговора по иниџиативе работодателя. Следовательно, Аолжен быть состав трудового правонарушения. Попытаемся его определить.

Субъектом аморацьного проступка явцяется работник, осуществляющий воспитательные функции. В соответствии с Федеральным законом «Об образовании в Российской Федерации» педагогическим работником явцяется физическое миџо, которое состоит в трудовых, служебных отношениях с организацией, осуществляющей образовательную деятельность, и выполняет обязанности по обучению обучающихся и (ики) организащии образоватемьной деятельности (подп. 21 ст. 2) [5] .

Пиенум Верховного Суаа РФ в постановлении от 17 марта 2004 г. № 2 «О применении судами Российской Федерации Трудового кодекса Российской Федерации» в п. 46 разъясняет, что к работникам, выполняющим воспитательную функцию, относятся, кроме учителей и преподавателей, мастера производственного обучения, воспитатели детских учреждений [10] .

Субъективная сторона аморального проступка состоит в виновном поведении в форме умысла или неосторожкности. Как отмечает М.Н. Малеина, форма вины и мотив совершения аморального проступка законодателем не учитывается, что очевидно явцяется пробелом. Специалисты обращают внима- 
ние на то, что в случае совершения аморального проступка вне рабочего места во внимание следует принимать умысел и факт распространения сведений об

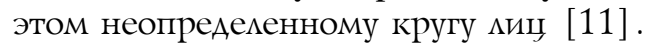

Объектом явцяется существующие в социуме морацьные устои. Так, в Федеральном законе «Об образовании в Российской Федерации» предусмотрена норма о том, что педагогические работники обязаны соблюдать нравственные и моральные нормы.

Объективная сторона аморацьного проступка состоит в действии или безАействии как по месту работы, так и вне его.

Итак, можно сделать вывод о том, что аморальный проступок - это оценочное понятие. Ввиду неоднозначности рассматриваемой категории на практике работодатель самостоятельно опредецяет аморальность содеянного. Вопросы степени аморальности и расторжения трудового договора с работником остается такжке на усмотрении работодателя, так как в законодательстве не предусмотрены квалифицирующие признаки данного деяния. В практике правоприменения по этому вопросу также наблюдается путаница. Представцяется необходимым введение Верховным Судом РФ критериев аморальности проступка. Реализация данного предложения позволит преодолеть широкое толкование аморального проступка работодатемями и судами и выработать еАиноОбразный подхоА.

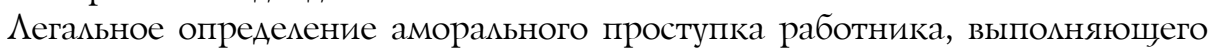
воспитательные функции, следует закрепить в ТК РФ.

Считаем верным в п. 8 ст. 81 ТК РФ рекомендовать законодателю дать расширенное толкование данного деяния, предусмотрев перечень действий, которые могут считаться аморацьным проступком, искиючив, при этом совершение указанного действия в быту.

В ТК РФ необходима новая статья, предусматривающая юридическую конструкщию аморацьного проступка и перечень деяний, считающихся Аця работников, выполняющих воспитательные функции.

В силу того что трудовое право регулирует трудовые и непосреАственно связанные с трудовыми отношения, целесообразно Аля обеспечения защиты педагогического работника от произвола администрации и иных недобросовестных участников образовательных отношений (в том числе недобросовестных родителей) сделать оговорку в ТК РФ о том, что мюбые Аействия педагогических работников вне места работы должны быть квалифицированы как гражданские и административные правонарушения, а не как Аеяния, предусмотренные п. 8 ст. 81 ТК РФ.

Норма, предусматривающая увольнение педагогических работников за совершение аморального проступка вне рабочего времени, в быту, по нашему мнению, противоречит принципу равенства и еще раз подчеркивает предвзятое отношение к педагогам, делая его юридически более уязвимым по сравнению с Аругими гражданами. Таким образом, педагогический работник не можкет быть уволен за совершение аморального проступка вне рабочего места и времени. 


\section{Библиографический список}

1. Трудовой кодекс Российской Федерации от 30 дек. 2001 г. № 197-Ф3 (с изм. от 16 дек. 2019 г. № 439-Ф3) // С3 РФ. 2002. № 1 (ч. 1). Ст. 3.

2. История о требовании уволить учительницу за покупку нижнего белья не подтвердилась. URL://https://zen.yandex.ru

3. Жильиов М., Слюмина О. Понятие «аморальный проступок» в трудовом праве // Кадровик. 2013. № 7. С. 33-37.

4. Минько Н.С. Прекращение трудового договора с работником, выполняющим воспитательные функции, в связи с совершением аморального проступка // Вестник Гродзенского журнала университета имени Ивана Купалы. Сер.: Юриспруденция. 2015. № 2 (191). С. 63-68.

5. Об образовании в Российской Федерации: Федер. закон от 29 дек. 2012 г. № 273-Ф3 (с изм. от 6 февр. 2020 г. № 9-Ф3) // СЗ РФ. 2012. № 53 (ч. 1). Ст. 7598.

6. Рекомендация о статусе преподавательских кадров учреждений высшего образования (Париж, 11 нояб. 1997 г.). URL: http: //lexed.ru/mpravo/razde

7. Апелляционное определение судебной коллегии по гражданским делам Алтайского краевого суда по делу № 33-6014/14. URL: http: //sudact.ru

8. Апелляционное определение Верховного суда Республики Татарстан от 8 февр. 2016 г. по делу № 33-2197/2016. URL: http: //sudact.ru

9. Кассационное определение Санкт-Петербургского городского суда от 20 дек. 2011 г. № 33-18965/2011. URL: http: //sudact.ru

10. О применении судами Российской Федерации Трудового кодекса Российской Федерации: постановление Пленума Верховного Суда РФ от 17 марта 2004 г. № 2 (в ред. от 24 нояб. 2015 г.) // Бюллетень Верховного Суда РФ. 2004. № 6.

11. Малеина М.Н. Аморальный проступок преподавателя: правовая оценка понятия и последствий в сфере трудового и гражданского права // Журнал российского права. 2018. № 10 . C. 61-72. 